CZU 321.01:351.86

https://doi.org/10.52388/1812-2566.2020.4(91).02

\title{
CHARACTERISTIC ASPECTS OF THE STATE AS THE CENTRAL INSTITUTION OF POLITICAL SYSTEM (from the perspective of the guarantor of national security)
}

\author{
Ludmila OLEINIC \\ Doctor of Political Science, Associate Professor, \\ The American University of Moldova, Republic of Moldova \\ e-mail: astmiler@mail.ru \\ https://orcid.org/0000-0002-5884-9563
}

The establishment of a democratic state, an open society in which the citizen is the subject of social-political processes and feels safe, represent in essence a complex process. The main role in achieving these objectives largely depends by the state, by the public power, which is essentially obliged to create the right conditions and mechanisms for the involvement of all progressive forces in the construction of the new edifice. In this vein, the factor of awareness of the state's correlation with national security is very important in order to make proposed objectives work. As a result, in order to increase the effectiveness the state focuses on reporting and accommodating to modern European standards and principles on the activity, organization and functioning of political processes and institutions in society as a whole in correlation with assuring national security issues.

Keywords: state, national security, state system, national interests, threat, political power, political regime, state institutions.

\section{ASPECTE CARACTERISTICE ALE STATULUI CA INSTITUȚIE CENTRALĂA SISTEMULUI POLITIC (perspectiva de garant al securității naționale)}

Constituirea unui stat democratic, a unei societăți deschise, în care cetățeanul este subiect al proceselor social-politice și se simte $\hat{\imath} n$ siguranță, reprezintă, $\hat{\imath} n$ esență, un proces complex. Rolul principal $\hat{\imath} n$ atingerea acestor obiective $\hat{\imath} i$ revine, în mare măsură, însăși statului, puterii publice, care este obligată să creeze condițile și mecanismele potrivite pentru implicarea tuturor forțelor progresiste în construcția noului edificiu. In acest sens, factorul de conștientizare a corelației statului cu securitatea națională este foarte important, pentru ca obiectivele propuse să funcționeze. Ca urmare, pentru a spori eficacitatea, statul se concentrează pe raportarea și adaptarea la standardele și principiile europene moderne privind activitatea, organizarea și funcționarea proceselor și instituțiilor politice în societate $\hat{i n}$ ansamblu, în corelație cu asigurarea securității naționale.

Cuvinte-cheie: stat, securitate națională, sistem de stat, interes național, amenințare, putere politica, regim politic, instituțiile statului. 


\section{ASPECTS CARACTÉRISTIQUES DE L'ÉTAT EN TANT QU'INSTITUTION CENTRALE DU SYSTÈME POLITIQUE \\ (point de vue du garant de la sécurité nationale)}

L'établissement d'un état démocratique, d'une société ouverte dans laquelle le citoyen fait l'objet de processus sociopolitiques et se sent en sécurité, est essentiellement un processus complexe. Le rôle principal dans la réalisation de ces objectifs incombe en grande partie à l'état lui-même, la puissance publique, qui est obligée de créer les bonnes conditions et mécanismes pour l'implication de toutes les forces progressistes dans la construction du nouvel édifice. En ce sens, le facteur de conscience de la corrélation de l'état avec la sécurité nationale est très important pour que les objectifs proposés fonctionnent. En conséquence, afin d'accroître l'efficacité, l'état se concentre sur l'établissement de rapports et l'adaptation aux normes et principes européens modernes sur l'activité, l'organisation et le fonctionnement des processus des institutions politiques dans la société dans son ensemble, en corrélation avec la garantie de la sécurité nationale.

Mots-clés: état, sécurité nationale, système de l'état, intérêt national, pouvoir politique, régime politique, institutions de l'état.

\section{ХАРАКТЕРНЫЕ ОСОБЕННОСТИ ГОСУДАРСТВА КАК ЦЕНТРАЛЬНОГО ИНСТИТУТА ПОЛИТИЧЕСКОЙ СИСТЕМЫ}

(с точки зрения гаранта национальной безопасности)

Создание демократического государства, открытого общества, в котором гражданин остается субъектом общественно-политических процессов и чувствует себя в безопасности, является, по сути, сложным процессом. Основная роль в достижении этих иелей во многом зависит от самого государства, от государственной власти, которая обязана создать благоприятные условия и механизмы для участия всех прогрессивных сил в строительстве нового типа государства. В этой связи, для достижения предлагаемых целей, значимую роль играет фактор осведомленности о взаимосвязи государства с национальной безопасностью. В итоге, в целях повыиения эффективности, государство сосредоточивает свое внимание на отчетности и адаптации к современным европейским стандартам и принциипам деятельности, организации и функционирования политических процессов и институтов в обществе в иелом, в сочетании с обеспечением национальной безопасности.

Ключевые слова: государство, национальная безопасность, наџиональные интересы, угроза, политическая власть, политический режим, государственные институть.

\section{Introduction}

The actuality of this research is determined by the need to assess the achievements of the state as the central institution of the political system while offering suggestions on perspective. Multiple aspects have manifested, which as relations of state elements and institutions, state theoretical approaches, state consolidation, correlation between the state and the national security system, the interests and the security environment, democracy, all are the subjects of present political scientific investigation. From the perspective of undeniable reality and needs the scientific research is to reveal truth with an important contemporary resonance. As a result, various methods of political science have been used and integrated as study tools. Is worth to be mentioned the systemic method, which allowed analyzing as a whole the investigated subject, revealed in the foreground. Similarly, in order to achieve the purpose of the scientific investigation, the comparative method and the history principle was widely applied. In direct accordance was used the political neoinstitutionalism, the essence of which is reflected by the thesis that institutions determine and limit historical and political developments. 


\section{The main ideas of the research}

The state as the central institution of the political system represents a specific organization of political power in society, which has sovereignty, monopoly on the use of legal constraint and achieves governance with society through a special mechanism. The contemporary state provides a set of characteristic features, which are recognized by the international community and are used as criteria for the recognition of other states as subjects of international relations, which have concrete rights and responsibilities. These criteria are three important constituent elements for the state. The first element, the territory as an indication of the state is indivisible, inviolable, inalienable and exclusive. The second one, the population constitutes the human community, which lives on the territory of the state and is subject to its power. According to international law, the population identifies with the inhabitants of the state. In turn, the third element is sovereignty, it requires being independent of any forces, situations or persons. The power of the state is sovereign, it has supremacy in the country and independence in relations with other states. Being sovereign, it means state power is universal first, secondly it has the prerogative to postpone any manifestations of any other community power and thirdly it has exclusive means of interaction (army, police).

It is the concept of purpose that distinguishes the concept of the state from its physical bases as well as its institutions. Physical foundations simply exist and must be addressed by virtue of this. Institutions are created to govern, to make the state work, but their functional logic fails in the long run seeking to include in definition the whole state. A clear suggestion as a valuable orientation to explore the notion of state is conferred by the concept of national security. National security emphasizes in a strong way that the object of security is the nation and this structures questions about the links between nation and state. Given these facts, every national security taken in stricto senso is a concept with a limited application in terms of the state, or in other words, the relationship between state and nation is much more complex. The objective of the state is to protect and represent the nation and the link between them is deep [1, p. 46].

National security is the main concern of the state, which is a state of legality, socio-economic balance and political stability of the state, in accordance with democratic principles and norms. In this context, national security is the basis of the general policy of the state by which theoretical foundation and implementation of measures in all fields of activity, with the aim of ensuring the promotion and defense of fundamental national interests. In other words, the nation can manage its security status only if it has high-performance "capture status" capabilities, designed to detect wide range of direct or discrete political (including military), energetic, informational, financial-banking, cultural aggressions [2, p. 9].

Can be concluded that the national security of the state represents the totality of the visions regarding the objectives and strategy of the state in the field of ensuring the security of the individual, society and the state from external and internal political, economic, social, military, technological, ecological, informational threats, taking into account the available resources and possibilities. From the perspective of the analyses made, the security of the nation has two fundamental components: internal security and external security. Each component must be managed from integrative perspective, in particular through the most efficient process and resource management, aiming to act and allocate resources for different 'projects'.

Internal security is aimed to social security and population protection, in many aspects and in cases such as natural disasters, pollution due to industrial 
accidents. Internal security manages economic or industrial espionage activity, corruption, sabotage or terrorist actions, attacks on strategic infrastructures. Internal security ensures the environment most conducive to economic development and the achievement of the well-being of citizens. In turn external security, concerns first and foremost possible military aggression, cross-border crime and the management of latent conflicts in the territorial proximity. They also include participation in various international missions, peacekeeping or peace-making.

Thus, national security reflects the main directions and principles of state policy, being the basis for the elaboration of concrete programmes and organizational documents in the field of its assurance. The main principles of national security are as follows: respect for the Constitution and the laws of the state in carrying out the activity on ensuring national security; unity, correlation and balance of all types of security, changing its priorities depending on the situation; priority of political, economic, informational measures to ensure national security; the reality of the objectives put forward in dependence of the resources and means available; compliance with the rules of international and national law in the execution of coercive measures, including the use of military force; the combination of centralized leadership of security forces and means with the transfer of tasks in this area to state power bodies, local and central state authorities [3, p. 267],

The protection of the national security of the state includes all political, economic, military and legal measures aimed at identifying, warning and suppressing the activity of anti-state forces, foreign intelligence services. Elements of the system of protection of state security constitute measures to prevent terrorist acts, to isolate objects with special purpose. The same, state security is carried out by various state bodies intended to ensure national security and above all by special bodies - espionage within and outside the country and counterintelligence.

It can certainly be said that national security is the state of the nation, social communities, citizens and the state, founded on economic prosperity, legality, balance and socio-political stability, expressed by the rule of law and ensured by actions of economic, political, social, legal, military, informational and other nature, with the aim of the unfettered exercise of citizens' rights and freedoms, the full manifestation of the freedom of decision and action of the state, its fundamental attributes and the quality of the subject of international law. In this vein, the elements of national security can be defined, such as:

* National defense include the measures and actions carried out by the state in order to defend and guarantee national sovereignty, state independence and unity, territorial integrity and constitutional democracy;

* National security is the guarantee provided by the state on the effective defense of democracy, the rule of law, constitutional order and supreme values guaranteed by the Constitution, through the intelligence, counterintelligence and security activities carried out by the national security system, as well as through decisions and actions to achieve the safety of citizens and the nation;

* Public order include the totality of political, economic, social norms and measures that allow the normal functioning of state institutions, the maintenance of public peace, the guarantee of the safety of citizens, respect and protection of rights».

With regard to 'security policy resources', three categories of objectives are highlighted, such as: application of resource management on the basis of integrated programmes to all institutions engaged in activities in the field of defense, public order and national security; ensuring better coordination of the institutions involved in securing resources, as well as 
the more effective exercise of parliamentary control; increasing transparency in the use of public funds and accountability to the taxpayer [4, p. 2].

As society develops around the state, it becomes increasingly dependent on state and therefore the security is indispensable linked to the state. The state is much more than the sum of its citizens and, as a result, complex relations are established between the state and its citizens that do not always satisfy all its citizens. Opinions on relations between the state and citizens are divided into two basic models such as minimalist and maximalist conceptions of the state.

In regard, the minimalist state has the genesis in John Locke's concept of social contract, which provides a theory of the state centered in particular on the individuals who make it up. The state is based on the consent of its citizens to be governed, and the actions of the state are appreciated by their impact on the interests of citizens. From this point of view, the state is the sum of its citizens, and serious conflicts between citizens and the state should be avoided. Robert Nozick provides a profound and comprehensive justification of the minimalist state, in which the recognized need for collective structures is subordinated to the primary value of individual rights [5, p. 58]. From this perspective, the interpretation of national security is derived from the interests of individual citizens, in which case conflicts of interest between citizens and the state do not become antagonistic.

In turn, the maximalist state has come from the assumption that the state should be much more than the sum of its component parts and that therefore has its own interests that do not, always correspond to those of the citizens. The interests of the state can derive from a variety of sources: maximalists interpret them as the interests of dominant elite, which uses the state to promote its own cause [6, p. 34], the realists conceive the state as a necessary unity for the good and survival of any human group within the international anarchic environment. Starting from Hegel's «deification» of the state, Heinrich von Treitschke argues that the state is «primary and necessary», that it exists as an «independent force» and that it «does not require opinions in an elementary way, but claims obedience» [7, p. 129]. From this perspective, the state as a collective entity is above the individuals who compose it and is not conceived as something created by individuals on the basis of a social contract.

Regardless of the approach, the state takes an independent position on its citizens because of the essential role it plays in the realization of individual interests. Since the state must be regarded as the source of any value, or at least as a necessary condition for the realization of any value, its maintenance and consequently the pursuit of its interests exceeds the individual values of which it is composed as a notion. Between the maximalist and minimalist approach of the state there are different interpretations of the relationship between individual security and national security. Since the state is more than the sum of its parts, it can detach itself from individual security needs, and therefore legitimately ignore them [8, p. 79].

In practice, it is the maximalist state that leads, the minimalist state remaining a utopia. R. Berki considers that there is no way out of the paradoxes of individual security without the existence of the state $[9$, p. 203]. The maximalist state remains a common practice, while the minimalist state's view is to set a standard for criticism. In the maximalist state model, internal security becomes a natural dimension and no efforts are necessary to harmonize the interests of the state with those of the individual one. Regardless of the type of state organization, political power must pay attention to citizens' problems because otherwise they risk one or both de- 
nouncements: the collapse of a civil war or the loss of international power and status vis-à-vis other states or security bodies.

As a result, the state represents a form of organization of political power that has a specific structure. The organization, structure and realization of state power presuppose the form of the state. The form of the state as a whole of external indications includes three elements: the form of state organization, the form of government and the political regime. The form of organization of the state represents the national-territorial organization of the state and a correlation of the central, regional bodies. In this regard, the main forms of state organization are the confederation, the unitary state and the federation. The form of government implies the method of organization of the higher state power, the principles of the correlation of its organs, the measure of participation of the population in their formation. There are two main forms of state governance such as the republic and the monarchy. The third element of the form of the state is the political regime which represents the totality of methods, processes, means of achieving political power. The political regime characterizes the environment and the conditions of the political life of society, a decisive political climate existing in one or another country during a concrete period of historical development. However, the political regime is a system of constitutional order and a concrete exposition of this system in practice $[10$, p. 66],

As demonstrated by the contemporary political practice of democratic countries, the prime subject of political power, its source is the people, who perform some of the functions of the corresponding power, another part delegates them to its official representative, to the state. In turn, the state divides the powers between the bearers of power. This division of power is called the division of powers. The idea of the division of powers (J.Lock, Ch. Montesquie) for the first time was reflected legally and practically in the U.S. Constitution, the Constitutional Acts of the Great French Revolution, which was later taken up by the political practice of other countries [11, p. 209],

The division of powers is carried out in two dimensions: vertically and horizontally. The vertically division of powers represents in itself the division of powers between the subjects of state leadership of different levels. In this way, the organs of central, regional and local power are formed. In practice, it distinguishes the division of states into centralized, where local power bodies are the «continuations» of central bodies (Greece, Ireland, Portugal, Iceland); decentralized states - local bodies (provinces, counties, departments) are empowered with substantial powers (Italy, Spain, France); semi-centralized states - the organs of local power in a row of spheres such as education, health protection have relative independence, and otherwise depend on the bodies of central power (United Kingdom, Netherlands).

The horizontally division of powers is carried out between three bodies sometimes being called «branches» of power - legislative, executive and judicial. Legislative power is based on the principles of the constitution and the rule of law, forming the outcome of the elections. In different countries the functions of the legislative power are different both by volume and content. But, as such, the legislative power has the following attributions: it introduces changes in the Constitution, determines the foundations of the internal and external policy of the state, adopts the state budget, initiates and adopts laws, binding on executive bodies and citizens, controls their execution. The bearer of the legislative power is the representative body - the Parliament, which can be made up of one chamber or two chambers. For example, the one-chamber parliament operates 
in eight out of eighteen Western European countries (Iceland, Luxembourg, Portugal, Greece, the Scandinavian countries). In a row of countries there is a two-chamber parliamentary system, in which one chamber is formed as a result of direct elections, and the second on the basis of territorial proportionality. Thus, in some countries (e.g. Belgium, Switzerland and Italy) both chambers are equal, participate equally in the formation of the government and in the legislative process.

In turn, executive power is even more diverse. In some countries (USA) the head of executive power is the president of the country, while holding the post of head of state. In other countries these functions are divided, having a dual character. For example, in countries with the form of republican government (such as Germany, France, Italy) the head of executive power is the prime minister and the head of state is the president. In Britain the head of state is the monarch, the head of the executive power is the prime minister. A peculiarity of the executive power is that it not only organizes the execution of decisions of the legislative power, but also alone can issue normative acts or rule with legislative initiative.

The judicial power has as its first prerogative the protection of the constitutional order of the state, the legality and order, the rights and freedoms of citizens. Its system includes organizations and institutions independent of other power bodies: these are the Constitutional Courts (such as in Austria, Spain, Portugal, Germany and Russia), the Constitutional Council (in France), the Special Higher Court (in Greece). The purpose of these bodies is to ensure the defense of the democratic system from the demands of the legislative, executive and to certain extent of the social power. In addition to the constitutional courts, in virtually all countries there are administrative judges, who resolve the differences that arise between citizens and governing bodies. Compliance with the laws is supervised by the prosecutor's office, and other control bodies [12, p. 15-16].

\section{Conclusions}

The specific approach is carried out in matters of the state, as a central institution in ensuring internal security, analyzing itself from the position of guarantor of national security assurance, the forms of state, governance and the division of powers in the state. Generalizing can be said that from strategic point of view, the state policy and national security are directing their efforts to guarantee the development of the state and society in terms of civilization and economy, towards its transformation into a functioning and stable democracy, towards creating and promoting favorable conditions for increasing the well-being of the population and the prosperity of the country, for the modernization of the state.

In this regard, building state and societal resilience by supporting good governance and accountable institutions by working closely with civil society is an important issue in order to make things work. Also, an integrated approach to state and national security being fully engaged in all levels of governance is expected to be successful through a coherent use of all policies. Finally, the cooperation between states will support forms governance and national security worldwide, allowing states and peoples the opportunity to better manage security concerns, reap the economic gains of globalization, express more fully cultures and identities, and project influence in world affairs.

\section{Bibliographic references}

1. BUZAN, B. People, States and Fear: The national Security Problem in International Relations. - Brighton, Harvester-Wheatsheaf. 1983. P. 44-53. 
2. www.cpcs.ro/dictionarsecuritate.php.

3. Dictionary of social sciences. - UK, Ed. by I.Gould Kolb. The Free Press. 1965. P.267.

4. http://www.securitatenationala/e107_plugins/content/content.php?content.11

5. REYNOLDS, P. Introduction to International Relation. - London, Longman. 1980. P. 58.

6. BLOCK, F., KAPLAN, B.H. Teoria marxistă a statului în analiza sistemelor mondiale. București, Ed. Academiei. 1978. P.34.

7. TREITSCHKE, H. Politics, Communism, Fascism and Democracy: The theoretical foundation. - New York, Random House, 1972. P. 129.

8. PETTMAN, R. State and Class: sociology of international affairs. - London, Croom Helm, 1979. P.79-82.

9. BERKI, R. Security and Society: Reflection on law, order politics. - London, J.M. Dent, 1986. P.203.

10. PÎRT,AC, G., OLEINIC, L. Manual de Politologie. Chișinău, Ed. Vizual Design, 2011. P. 64-71.

11. ИРХИН, Ю. Политология. - М.: Экзамен, 2006. C. 209 .

12. OLEINIC, L. Note de curs. Politologie. Partea I. - Chișinău, Ed. AAP. 2010. P.15-16. 